\title{
Synthesis, characterization and anticancer studies of some morpholine derived Schiff bases and their metal complexes
}

\author{
Nura Suleiman Gwaram ${ }^{1,2}$, , Pouya Hassandarvish ${ }^{3}$ \\ ${ }^{1}$ Chemistry Department, Faculty of Science, University of Malaya, 50603 Kuala Lumpur, Malaysia. \\ ${ }^{2}$ Chemistry Department, Faculty of Natural and Applied Sciences, Umaru Musa Yar'adua University, P .M.B. 2218 Katsina, Nigeria. \\ ${ }^{3}$ Molecular Medicine Department, Faculty of Medicine, University of Malaya, 50603 Kuala Lumpur, Malaysia.
}

\section{ARTICLE INFO \\ Article history: \\ Received on: 21/06/2014 \\ Revised on: 13/07/2014 \\ Accepted on: 02/08/2014 \\ Available online: 30/10/2014}

Key words:

Schiff bases metal

complexes; Anticancer;

MCF-7, WRL68.

\begin{abstract}
This paper reported series of complexes and their modes of coordination. The series consist of $N, N^{\prime}, O$-donor Schiff base formed by condensation reaction of 2-hydroxyacetophenone with 4-(2-aminoethyl)morpholine. The ligand and complexes were characterized by elemental analysis, FT-IR, NMR and UV/Visible spectroscopy. The complexes showed moderate cytotoxicity mediated on MCF-7 breast cancer cell line and were selective to some extent when compared to the WRL68 normal liver cell line.
\end{abstract}

\section{INTRODUCTION}

Schiff base compounds derived from morpholine are completely stable in biological systems, allowing rigorous longterm applications as they constitute a radical re-design of DNA (Summerton, 2007) these important factors are considered in designing this morpholine derived ligands and their metal complexes for their potential anticancer applications. First row transition metals play major roles in various biological activities because of the exceptionally wide range of reactivity available and have been particularly attractive (Petrovic et. al., 1996). It is also known that the existence of metal ions bonded to biologically active compounds may enhance their biological activities, such as antibacterial (Prakash, 2010), anticonvulsant (Sridhar, 2002), antifungal (Bharti et. al., 2010), anti-HIV (Pandeya et. al., 1999), antiviral and anticancer (Creaven et. al., 2010, Garoufis et. al., 2009, Raman et. al., 2010, Shakir et. al., 2011, Zhang et. al., 2009) and antimicrobial (Mandal et. al., 2011, Yusnita et. al., 2009, Pignatello et. al., 1994, Nair et. al., 2001, Tajudeen, 2009, Xue et. al., 2011), DNA binding and DNA cleavage activities

\footnotetext{
* Corresponding Author

E-mail: nura_suleiman@yahoo.com
}

(Shahabadi, 2010) and many other biological activities (Mladenova et. al., 2002, Bagihalli, 2008, El-Sherif, 2011, Creaven et. al., 2010, Wang et. al., 2005). Varieties of metal complexes have been used as drugs and are well known to increase their activity or when administered as metal complexes show higher activity towards specific targets (Moriuchi, 1999, Moriuchi et. al., 2000, Bauer, 1999).

In this study, metal complexes of some newly synthesized $N N^{\prime} O$ donor Schiff base ligands from the reaction of 4-(2aminoethyl)morpholine with 2-hydroxyacetophenone (scheme 1), were examined for potential anti-cancer applications.

\section{EXPERIMENTAL SECTION}

\section{Materials and methods \\ Chemical and reagents}

4-(2-aminoethyl)morpholine, 2-hydroxyacetophenone, copper(II) chloride, manganese(II) chloride, nickel(II) chloride, zinc(II) chloride, glacial acetic acid, triethylamine, absolute ethanol (99.8\%), ethanol (95\%), dimethylsulphoxide and Deuterated dimethylsulphoxide were purchased from the AldrichSigma Company. $95 \%$ Ethanol was distilled prior to use. 


\section{Melting Point Determination}

Melting points were determined using a MEL-TEMP II melting point instrument. All samples are placed in the micro haemotocrit tube (soda lime glass). The melting points of the sample were recorded after they have completely melted.

\section{Carbon, Hydrogen and Nitrogen (CHN) Analyses}

Microanalyses for carbon, hydrogen and nitrogen in the compounds were carried out on a Perkin-Elmer 2400 elemental analyzer. All compounds (1.75-2.00 mg) were weighted in aluminium foil capsules. The instrument was calibrated with sulfamethinezine.

\section{Infra Red (IR) Spectroscopy}

The Infrared spectra were recorded on a Perkin Elmer Spectrum 400 ATR-FT-IR spectrometer at the Department of Chemistry, Faculty of science University of Malaya. All the spectra were run in the range of $400-4000 \mathrm{~cm}^{-1}$ at room temperature.

\section{Nuclear Magnetic Resonance (NMR) Spectroscopy}

The ${ }^{1} \mathrm{H}$ and ${ }^{13} \mathrm{C}$ NMR spectra of the Schiff bases were recorded using a Bruker Apex 600MHz; FT-NMR spectrometers chemical shifts are given in $\delta$ values (ppm) using TMS as the internal standard. Deuterated dimethylsulphoxide (DMSO) was used as solvent.

\section{Ultraviolet-Visible (UV-Vis) Spectroscopy}

The spectra (solid) were obtained from reflectance electronic technique by using UV-3600 Shimadzu UV-Vis-NIR Spectrophotometer and were scan from 200-1000, while the spectra (DMSO) were recorded in quartz cuvettes on a Shimadzu 1601 spectrophotometer in the region of $200-1000 \mathrm{~nm}$.

\section{Cell Lines}

Human cell lines will be obtained from the American Type Culture Collection ATCC, USA.

\section{SYNTHESIS OF THE COMPOUNDS}

\section{2-(1-(2-morpholinoethylimino)ethyl) phenol (L1)}

The ligand was obtained from the condensation reaction of 2-hydroxyacetophenone with 4-(2-aminoethyl)morpholine in the presence of few drops of glacial acetic acid to adjust the $\mathrm{pH}$. The product is oily orange solution was formed, which became orange colored hygroscopic solid after 12 hours at $55^{\circ} \mathrm{C}$ in an oven. The solid product was dissolved in methanol and heated to $60{ }^{\circ} \mathrm{C}$. After evaporating from the solvent under reduced pressure, an orange colored solid was formed. This ligand was characterized by using melting point, elemental analysis, IR, NMR and UV/Visspectroscopy. Yield: 55.2\%. Molecular formula: $\mathrm{C}_{14} \mathrm{H}_{20} \mathrm{~N}_{2} \mathrm{O}_{2}$, Molecular Weight: 248.15. ${ }^{1} \mathrm{H}-\mathrm{NMR}\left(600 \mathrm{MHz}, \delta\right.$, DMSO- $\left.d_{6}\right)$ : 11.50 (1H-Phenolic), 7.50-6.98 (4H, CH-Ar), 3.98-3.66 $\left(\mathrm{CH}_{2^{-}}\right.$ Morph), 3.10-2.80 $\left(\mathrm{NCH}_{2}-\mathrm{CH}_{2} \mathrm{~N}\right), 1.24\left(\mathrm{CH}_{3}\right),{ }^{13} \mathrm{C}-\mathrm{NMR}(600$
$\left.\mathrm{MHz}, \delta, \mathrm{DMSO}-d_{6}\right): 166.54$ (C=N, Schiff) 146.46 (C-aromatic), 138.41 (CH-aromatic), 125.97 (CH-aromatic), $121.81 \quad(\mathrm{CH}$ aromatic), 63.20, 61.45 (2C, $\mathrm{CH}_{2}$-aliphatic), 50.67 (2C, $\mathrm{CH}_{2}-$ morpholine), 42.21 (1C, $\mathrm{CH}_{2}-$ morpholine), 33.83 (2C, $\mathrm{CH}_{2}-$ morpholine), $13.82\left(\mathrm{CH}_{3}\right.$-Methyl).

\section{COORDINATED COMPLEXES FOR L1}

A series of copper(II), manganese(II), nickel(II) and zinc(II) complexes of $\mathbf{L 1}$ Schiff base were prepared in situ by mixing 2-hydroxyacetophenone $(0.20 \mathrm{~g}, 1.65 \mathrm{mmol})$ and 4-(2aminoethyl $)$ morpholine $(0.21 \mathrm{~g}, 1.65 \mathrm{mmol})$ in ethanol $(20 \mathrm{ml})$ and refluxed. After $2 \mathrm{hr}$ an ethanolic solution containing metal(II) halides was then added and the mixtures were refluxed for 2-5 hours (Scheme 1). The resultant precipitates were filtered off, washed with cold ethanol and dried under vacuum. Physical properties of the synthesized compounds summarized can be found in (Table 1). The obtained compounds were further characterized by using CHN, FT-IR, UV-Visible and FT-NMR. The parameters are summarized in (Tables 1-3). The crystals structure for some of the complex was reported (Hisham, 2011). ${ }^{1} \mathrm{H}-\mathrm{NMR}$ [Zn(L1)Cl] (600 MHz, $\delta$, DMSO- $d_{6}$ ): 8.30-7.85 (4H, aromatic protons), 3.98$3.69\left(8 \mathrm{H}, \quad \mathrm{CH}_{2}\right.$ morpholine $), \quad 2.75-2.55 \quad\left(4 \mathrm{H}, \quad \mathrm{NCH}_{2}-\mathrm{CH}_{2} \mathrm{~N}\right.$ ethylenediamine protons), $2.30\left(3 \mathrm{H}, \mathrm{CH}_{3}\right.$ methyl ketone protons). ${ }^{13} \mathrm{C}-\mathrm{NMR}\left(600 \mathrm{MHz}, \delta\right.$, DMSO- $\left.d_{6}\right)$ : 168.00 (C aromatic carbon), 158.01 ( $\mathrm{CH}$ aromatic carbon), 156.64 ( $\mathrm{CH}$ aromatic carbon), 149.50 ( $\mathrm{CH}$ aromatic carbon), 137.22 ( $\mathrm{CH}$ aromatic carbon), 134.40 ( $\mathrm{CH}$ aromatic carbon), $65.60\left(2 \mathrm{C}, 2 \mathrm{CH}_{2}\right.$ ethylenediamine carbons), 56.45 (2C, $2 \mathrm{CH}_{2}$ morpholine carbons), 46.00 (1C, $\mathrm{CH}_{2}$ morpholine carbon), 42.67 (1C, $\mathrm{CH}_{2}$ morpholine carbon), 18.90 (1C, $\mathrm{CH}_{3}$ methyl ketone carbon). ${ }^{1} \mathrm{H}-\mathrm{NMR}$ [Zn(L1)Br] (600 MHz, $\delta$, DMSO- $\left.d_{6}\right)$ : 7.50-6.98 (4H, aromatic protons), 3.98-3.66 $\left(\mathrm{CH}_{2}\right.$ morpholine), 3.10-2.80 (2H, $\left.\mathrm{NCH}_{2}-\mathrm{CH}_{2} \mathrm{~N}\right), 2.24\left(3 \mathrm{H}, \mathrm{CH}_{3}\right.$, methyl ketone protons). ${ }^{13} \mathrm{C}-\mathrm{NMR}\left(600 \mathrm{MHz}, \delta\right.$, DMSO- $\left.d_{6}\right): 167.52(1 \mathrm{C}$, $\mathrm{C}=\mathrm{N}), 149.46$ ( $\mathrm{C}$ aromatic carbon), $146.60(\mathrm{CH}$ aromatic carbon), 141.40 ( $\mathrm{CH}$ aromatic carbon), 126.90 ( $\mathrm{CH}$ aromatic carbon), 120.80 ( $\mathrm{CH}$ aromatic carbon), 60.40 (2C, 2 $\mathrm{CH}_{2}$ ethylenediamine carbons), 53.09 (2C, 2 $\mathrm{CH}_{2}$ morpholine carbons), 51.67 (1C, $\mathrm{CH}_{2}$ morpholine carbon), 43.22 ( $1 \mathrm{C}, \mathrm{CH}_{2}$ morpholine carbon), 15.81 (1C, $\mathrm{CH}_{3}$ methyl ketone carbon).

\section{MTT - CULTURE OF CELLS AND CYTOTOXICITY ASSAY}

The MCF-7 cells (human breast cancer cells) were seeded into 96 well plates at an initial cell density of approximately $5 \times 10^{5}$ cells $\mathrm{cm}^{-3}$. After 24 hours incubation for cell attachment and growth, the medium was removed and replaced with fresh medium containing varying concentrations of the compounds. The compounds added were first dissolved in DMSO at the required concentration. Subsequent 6 desirable concentrations was prepared using growth medium. Control wells received only DMSO. Each concentration of the compound under study was assayed in six replicates. The assay was terminated after 
48 hours incubation period. Again, the medium was removed and cell viability was determined after further 4 hours with $5 \mathrm{mg} \mathrm{cm}^{-3}$ MTT [3-(4,5-dimethylthiazol-2-yl)-2,5-diphenyltetrazolium] bromide; also named thiazol blue. DMSO was then added per well and the dissolving formazan precipitate was read by using elisa plate reader, Dynatech MR5000 at $570 \mathrm{~nm}$. And comparison was made with positive control cisplatin.

\section{RESULTS AND DISCUSSION}

\section{Synthesis and characterization}

The reaction of 4-(2-aminoethyl)morpholine with 2hydroxyacetophenone resulted in the formation of corresponding Schiff base ligand; 2-(1-(2-morpholinoethylimino)ethyl) phenol (L1) The prepared Schiff bases further reacted copper(II), manganese(II), nickel(II) and zinc(II) giving rise to different coordination complexes (Scheme 1). The compounds exhibited NMR, IR and UV-Visible spectra consistent with the proposed structures which allowed the synthesized complexes to be recognized as Chlorido(2-\{1-[(2-morpholinoethyl)-imino]ethyl\} phenolato- $\left.\kappa^{3} N, N, O\right)$-copper(II) $\quad[\mathbf{C u}(\mathbf{L} \mathbf{1}) \mathbf{C l}], \quad B r o m i d o(2-\{1-[(2-$ morpholinoethyl)-imino]ethyl $\}$ phenolato- $\left.{ }^{3} N, N^{\prime}, O\right)-\operatorname{copper(II)}$ $[\mathbf{C u}(\mathbf{L} \mathbf{1}) \mathbf{B r}], \quad$ Chlorido(2-\{1-[(2-morpholinoethyl)-imino]ethyl $\}$ phenolato- $\left.\kappa^{3} N, N^{\prime}, O\right)$-zinc(II) $\quad[\mathbf{Z n}(\mathbf{L 1}) \mathbf{C l}], \quad \operatorname{Bromido}(2-\{1-[(2-$ morpholinoethyl)- imino]ethyl $\}$ phenolato- $\left.\kappa^{3} N, N^{\prime}, O\right)$-zinc(II) [Zn(L1)Br], Chlorido(2-\{1-[(2-morpholinoethyl) -imino]ethyl $\}$ phenolato- $\left.\kappa^{3} N, N^{\prime}, O\right)$-nickel(II) $\quad[\mathbf{N i}(\mathbf{L 1}) \mathbf{C l}], \quad \operatorname{Bromido}(2-\{1-[(2-$ morpholinoethyl)- imino]ethyl $\}$ phenolato- $\left.\kappa^{3} N, N^{\prime}, O\right)$ - nickel(II) [Ni(L1)Br], 2-(1-(2-morpholinoethylimino)ethyl)-phenoxy)manganese(II)chloride $\quad[\mathbf{M n}(\mathbf{L} \mathbf{1}) \mathbf{C l}], \quad$ 2-(1-(2-morpholinoethylimino)ethyl)-phenoxy)-manganese(II)bromide $[\mathbf{M n}(\mathbf{L 1} \mathbf{B}) \mathbf{B r}$. In this context, we would like to compare the structures of some earlier prepared complexes with the present ones. There are two reported complexes of nickel(II) perchlorate with the similar donor-Schiff base ligand (Chiumia et al., 1999 and Bhowmik et al., 2010). Elemental analysis data and physical properties of ligand and complexes are summarized in (Table 1); ligand was obtained in a liquid form. The reaction of ligands with transition metals produced a series of metal complexes with different colors. The data obtained from the melting point apparatus showed that the complexes' melting point were higher than $300{ }^{\circ} \mathrm{C}$. The percentages of $\mathrm{C}, \mathrm{H}$ and $\mathrm{N}$ obtained are in agreement with calculated values. The IR spectra of transition metal complexes were carried out in $4000-400 \mathrm{~cm}^{-1}$ range. The characteristic IR stretching frequencies of the metal complexes along with their proposed assignments are summarized in (Table 2). There are similarities in the IR spectrum of the metal complexes to each other, except for some slight variations in the shifts and intensities of few vibration peaks caused by different metal (II) ions, indicating that the metal complexes had similar structure. However, there were no significant differences between the metal(II) halides complexes as expected. The IR spectra of all the complexes possess very strong characteristic absorption bands in the region of $1670.00-1650.00 \mathrm{~cm}^{-1}$ which is attributed to the $\mathrm{C}=\mathrm{N}$ stretching vibration of the Schiff base imino functional group (Raman, 2011, Khan et. al., 2011, Nakamoto, 1978, Inamur et. al., 2001, Banerjee et. al., 2005). The spectra for the complex showed $\mathrm{M}-\mathrm{N}$ bands at a lower wavelength in the range of $477-575 \mathrm{~cm}^{-1}$ (Raman, 2011 and Khan, 2011). The electronic spectra for the free ligands were obtained and showed absorption band in three distinct regions.

The first region ranging from 270 to approximately 290 $\mathrm{nm}$, is characteristic for the electronic inter-ligand $\pi \rightarrow \pi^{*}$ transitions (Mohamed et. al., 2009), while the second characteristic wavelength in the region of $320 \mathrm{~nm}$ to approximately $450 \mathrm{~nm}$ is the second inter ligand $\mathrm{n} \rightarrow \pi$ transition of the $\mathrm{C}=\mathrm{C}$ and $\mathrm{C}=\mathrm{N}$ chromophores (Yusnita et. al., 2009). The third distinct region in the complexes ranging from $450 \mathrm{~nm}$ to approximately $500 \mathrm{~nm}$ is the characteristic for the ligand to metal charge transfer (LMCT) from the nitrogen atom to the transition metal centre (Yusnita et. al., 2009). The last distinct region ranging from $600 \mathrm{~nm}$ to approximately $780 \mathrm{~nm}$ is the characteristic for inter metal $\mathrm{d} \rightarrow \mathrm{d}^{*}$ transition (Yusnita et. al., 2009). The $\mathrm{Cu}$ (II) ion with its $\mathrm{d}^{9}$ configuration in tetrahedral environment is highly susceptible to Jahn-Teller distortion. The spectrum of $\mathrm{Cu}(\mathrm{II})$ complexes $\mathrm{Cu}(\mathrm{L} 1) \mathrm{Cl}$ and $\mathrm{Cu}(\mathrm{L} 1) \mathrm{Br}$ showed three bands in the visible region at 594, 726, $744 \mathrm{~nm}$ and 403, 596, 778 respectively. These are assigned to the transitions ${ }^{1} \mathrm{~A}_{1 \mathrm{~g}} \rightarrow{ }^{1} \mathrm{~B}_{1 \mathrm{~g}},{ }^{1} \mathrm{~A}_{1 \mathrm{~g}} \rightarrow{ }^{1} \mathrm{~A}_{2 \mathrm{~g}}$ and ${ }^{1} \mathrm{~A}_{1 \mathrm{~g}} \rightarrow{ }^{1} \mathrm{E}_{\mathrm{g}}$ respectively consistent with distorted square planar geometry (Shayma, 2010). Nickel(II), which has a $d^{8}$ configuration, commonly exhibits octahedral, square planar and tetrahedral coordination geometries. The electronic spectra of $\mathrm{Ni}(\mathrm{II})$ complexes $\mathrm{Ni}(\mathrm{L} 1) \mathrm{Cl}$ and $\mathrm{Ni}(\mathrm{L} 1) \mathrm{Br}$ showed d-d transitions in the region of 574, 845 and, 372, 597, 778 respectively. These are assigned to the transitions ${ }^{3} \mathrm{~T}_{1(\mathrm{~F})} \rightarrow{ }^{3} \mathrm{~A}_{2(\mathrm{~F}),}{ }^{3} \mathrm{~T}_{1(\mathrm{~F})} \rightarrow{ }^{3} \mathrm{~T}_{1(\mathrm{P})}$ and ${ }^{3} \mathrm{~T}_{1(\mathrm{~F})}$ $\rightarrow{ }^{3} \mathrm{~T}_{2(\mathrm{~F})}$ consistent with distorted square planar geometry (Shaker, 2010, Cotton, 1998, Selbin, 1983). The electronic spectra of $\mathrm{Mn}^{2+}$ $d^{5}$ complexes $\mathrm{Mn}(\mathrm{L} 1) \mathrm{Cl}$ and $\mathrm{Mn}(\mathrm{L} 1) \mathrm{Br}$ indicate that they have tetrahedral geometries. The ${ }^{6} \mathrm{~A}_{1} \rightarrow{ }^{4} \mathrm{E}(\mathrm{D})$ and ${ }^{6} \mathrm{~A}_{1} \rightarrow{ }^{4} \mathrm{~T}_{2}(\mathrm{D})$ can attributed to the band at $307,628,745$ and $229,307,712 \mathrm{~nm}$ respectively (Shayma, 2009). Lastly the electronic spectra for $\mathrm{Zn}$ (II) and $\mathrm{Cd}(\mathrm{II})$ complexes with an electronic configuration of $d^{I 0}$ the absorption bands observed were due to charge transfer transitions which suffered from blue shift with hyper chromic effect (Ceyhan, 2011). All these absorptions for the free ligands and their corresponding metal complexes have been fully assigned in (Table 3). Fourier transforms nuclear magnetic resonance (FTNMR) for the coordinated complexes have been summarized in the experimental part.

The chemical shift in the region 8.70-7.80 ppm, were observed for complexes respectively and they were assigned to the aromatic ring protons. The other single peaks appeared in the region $2.60 \mathrm{ppm}-2.90 \mathrm{ppm}$ respectively were attributed to $\delta\left(\mathrm{CH}_{3}\right)$ indicating the methyl on the carbonyl group in the complexes. In the ${ }^{13} \mathrm{C}$ NMR spectra of the metal complexes, the signal at region of $165.00 \mathrm{ppm}-170.00$ can be assigned to the azomethine $(\mathrm{C}=\mathrm{N})$ carbon atoms for complexes. Aromatic ring carbon atoms of the ligands were determined in the region of $120.00-160.00 \mathrm{ppm}$. 
<smiles>CC(=O)c1ccccc1O</smiles>

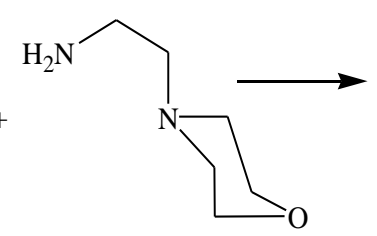<smiles>CC(=N)c1ccccc1O</smiles>

Scheme 1: Synthetic pathway for the Schiff base ligand and its metal complexes

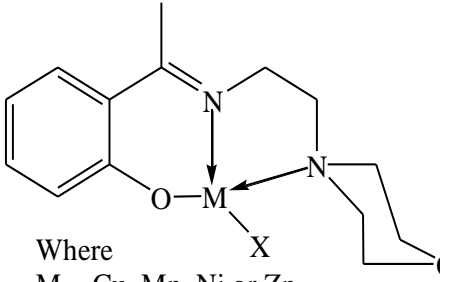

$\mathrm{M}=\mathrm{Cu}, \mathrm{Mn}, \mathrm{Ni}$ or $\mathrm{Zn}$ $\mathrm{X}=\mathrm{Cl}^{-}$or $\mathrm{Br}^{-}$

Table 1: The physical properties of the ligands and their metal complexes.

\begin{tabular}{|c|c|c|c|c|c|c|c|}
\hline \multirow{2}{*}{ Compound } & \multirow{2}{*}{$\begin{array}{l}\text { Mol.W. } \\
\text { (g/mol) }\end{array}$} & \multirow{2}{*}{ Color } & \multirow{2}{*}{ M.P $\left({ }^{\circ} \mathrm{C}\right)$} & \multirow{2}{*}{$\begin{array}{c}\text { Yield } \\
(\%)\end{array}$} & \multicolumn{3}{|c|}{ Elemental Percentage (\%) Calculated (Found) } \\
\hline & & & & & $\mathrm{C}$ & $\mathrm{H}$ & $\mathrm{N}$ \\
\hline L1 & 248.15 & Yellow & - & 65 & $67.71(68.19)$ & $8.12(7.89)$ & $11.28(11.48)$ \\
\hline $\mathrm{Cu}(\mathrm{L} 1) \mathrm{Cl}$ & 346.31 & Blue & $345-350$ & 83 & $48.55(48.49)$ & $5.53(5.71)$ & $8.09(8.39)$ \\
\hline $\mathrm{Cu}(\mathrm{L} 1) \mathrm{Br}$ & 390.76 & Brown & $355-360$ & 78 & $43.03(43.19)$ & $4.90(4.11)$ & $7.17(7.29)$ \\
\hline $\mathrm{Zn}(\mathrm{L} 1) \mathrm{Cl}$ & 348.16 & White & $>400$ & 82 & $48.30(48.48)$ & $5.50(5.79)$ & $8.05(8.98)$ \\
\hline $\mathrm{Zn}(\mathrm{L} 1) \mathrm{Br}$ & 392.61 & Milky & $345-350$ & 87 & $42.83(42.94)$ & $4.88(4.88)$ & 7.14(7.24) \\
\hline $\mathrm{Ni}(\mathrm{L} 1) \mathrm{Cl}$ & 341.46 & Green & $360-365$ & 76 & $49.24(49.25)$ & $5.61(5.63)$ & $8.20(8.50)$ \\
\hline $\mathrm{Ni}(\mathrm{L} 1) \mathrm{Br}$ & 385.91 & Greenish & $>400$ & 68 & $43.57(44.00)$ & $4.96(5.01)$ & $7.26(7.28)$ \\
\hline $\mathrm{Mn}(\mathrm{L} 1) \mathrm{Cl}$ & 337.70 & Reddish & $380-385$ & 73 & 49.79(48.99) & $5.67(5.54)$ & $8.30(8.40)$ \\
\hline $\mathrm{Mn}(\mathrm{L} 1) \mathrm{Br}$ & 382.15 & Brown & $>400$ & 65 & $44.00(43.97)$ & $5.01(5.17)$ & $7.33(7.40)$ \\
\hline
\end{tabular}

Table 2: The characteristic infrared absorptions of ligands and their metal complexes.

\begin{tabular}{|c|c|c|c|c|c|c|c|}
\hline Compound & $v(\mathrm{C}-\mathrm{H})$ & $v\left(\mathrm{SCN} / \mathbf{N}_{3}\right)$ & $v(\mathrm{C}=\mathrm{N})$ & $v(C-C)$ & $v(\mathrm{C}-\mathrm{N})$ & $v($ M-N $)$ & $v($ M-O $)$ \\
\hline L1 & 2952 & - & 1611 & 1448 & & & \\
\hline $\mathrm{Cu}(\mathrm{L} 1) \mathrm{Cl}$ & 2972 & - & 1580 & 1432 & 1113 & 526 & 493 \\
\hline $\mathrm{Cu}(\mathrm{L} 1) \mathrm{Br}$ & 3109 & - & 1664 & 1428 & 1113 & 531 & 473 \\
\hline $\mathrm{Zn}(\mathrm{L} 1) \mathrm{Cl}$ & 2984 & - & 1654 & 1438 & 1125 & 541 & 453 \\
\hline $\mathrm{Zn}(\mathrm{L} 1) \mathrm{Br}$ & 3076 & - & 1654 & 1438 & 1115 & 557 & 454 \\
\hline $\mathrm{Ni}(\mathrm{L} 1) \mathrm{Cl}$ & 2943 & - & 1605 & 1436 & 1121 & 518 & 474 \\
\hline $\mathrm{Ni}(\mathrm{L} 1) \mathrm{Br}$ & 2980 & - & 1597 & 1441 & 1102 & 516 & 492 \\
\hline $\mathrm{Mn}(\mathrm{L} 1) \mathrm{Cl}$ & 2974 & - & 1651 & 1442 & 1157 & 522 & 461 \\
\hline $\mathrm{Mn}(\mathrm{L} 1) \mathrm{Br}$ & 2838 & - & 1650 & 1464 & 1165 & 555 & 462 \\
\hline
\end{tabular}

Table 3: U.V - visible spectra of free ligands and their metal complexes 10-4 in DMSO and Solid state.

\begin{tabular}{|c|c|c|c|c|}
\hline Compound & $\lambda_{\max }$ & ABS & $\varepsilon_{\max }\left(\operatorname{Lmol}^{-1} \mathbf{c m}^{-1}\right)$ & Assignment \\
\hline \multirow{2}{*}{ L1 } & 321 & 2.817 & 5634.00 & $\mathrm{n} \rightarrow \pi^{*}$ \\
\hline & 396 & 0.749 & 1498.00 & $\mathrm{n} \rightarrow \pi^{*}$ \\
\hline \multirow{5}{*}{$\mathrm{Cu}(\mathrm{L} 1) \mathrm{Cl}$} & 279 & 1.551 & 3102.00 & C.T. M $\rightarrow \mathrm{L}$ \\
\hline & 358 & 1.470 & 2942.00 & C.T. $\mathrm{M} \rightarrow \mathrm{L}$ \\
\hline & 594 & 0.231 & 462.00 & ${ }^{2} \mathrm{~B}_{2} \mathrm{~g}_{(\mathrm{D})} \rightarrow{ }^{2} \mathrm{~B}_{1} \mathrm{~g}_{(\mathrm{D})}$ \\
\hline & 726 & 0.162 & 324.00 & ${ }^{2} \mathrm{E}_{2} \mathrm{~g}_{(\mathrm{D})} \rightarrow{ }^{2} \mathrm{~B}_{1} \mathrm{~g}_{(\mathrm{D})}$ \\
\hline & 744 & 0.110 & 220.00 & ${ }^{2} \mathrm{E}_{2} \mathrm{~g}_{(\mathrm{D})} \rightarrow{ }^{2} \mathrm{~B}_{1} \mathrm{~g}_{(\mathrm{D})}$ \\
\hline \multirow{3}{*}{$\mathrm{Cu}(\mathrm{L} 1) \mathrm{Br}$} & 403 & 3.215 & 6430.00 & ${ }^{1} A_{1 g} \rightarrow{ }^{1} B_{1 g}$ \\
\hline & 596 & 0.734 & 1468.00 & ${ }^{1} \mathrm{~A}_{1 \mathrm{~g}} \rightarrow{ }^{1} \mathrm{~A}_{2 \mathrm{~g}}$ \\
\hline & 778 & 0.090 & 180.00 & ${ }^{1} \mathrm{~A}_{1 \mathrm{~g}} \rightarrow{ }^{1} \mathrm{E}_{\mathrm{g}}$ \\
\hline \multirow{2}{*}{$\mathrm{Ni}(\mathrm{L} 1) \mathrm{Cl}$} & 574 & 0.374 & 748.00 & ${ }^{3} \mathrm{~T}_{1(\mathrm{~F})} \rightarrow{ }^{3} \mathrm{~T}_{1(\mathrm{P})}$ \\
\hline & 845 & 0.224 & 448.00 & ${ }^{3} \mathrm{~T}_{1(\mathrm{~F})} \rightarrow{ }^{3} \mathrm{~T}_{2(\mathrm{~F})}$ \\
\hline \multirow{3}{*}{$\mathrm{Ni}(\mathrm{L} 1) \mathrm{Br}$} & 372 & 2.635 & 5270.00 & ${ }^{3} \mathrm{~T}_{1(\mathrm{~F})} \rightarrow{ }^{3} \mathrm{~A}_{2(\mathrm{~F})}$ \\
\hline & 597 & 0.332 & 664.00 & ${ }^{3} \mathrm{~T}_{1(\mathrm{~F})} \rightarrow{ }^{3} \mathrm{~T}_{1(\mathrm{P})}$ \\
\hline & 778 & 0.063 & 126.00 & ${ }^{3} \mathrm{~T}_{1(\mathrm{~F})} \rightarrow{ }^{3} \mathrm{~T}_{2(\mathrm{~F})}$ \\
\hline \multirow{4}{*}{$\mathrm{Mn}(\mathrm{L} 1) \mathrm{Cl}$} & 307 & 1.068 & 2056.00 & ${ }^{6} \mathrm{~A}_{1} \rightarrow{ }^{4} \mathrm{E}_{(\mathrm{D})}$ \\
\hline & 628 & 0.114 & 228.00 & ${ }^{6} \mathrm{~A}_{1} \rightarrow{ }^{4} \mathrm{~T}_{2(\mathrm{D})}$ \\
\hline & 728 & 0.126 & 252.00 & \\
\hline & 745 & 0.078 & 156.00 & \\
\hline \multirow{3}{*}{$\mathrm{Mn}(\mathrm{L} 1) \mathrm{Br}$} & 229 & 0.241 & 482.00 & ${ }^{6} \mathrm{~A}_{1} \rightarrow{ }^{4} \mathrm{E}_{(\mathrm{D})}$ \\
\hline & 307 & 1.068 & 2136.00 & ${ }^{6} \mathrm{~A}_{1} \rightarrow{ }^{4} \mathrm{~T}_{2(\mathrm{D})}$ \\
\hline & 712 & 0.112 & 224.00 & \\
\hline $\mathrm{Zn}(\mathrm{L} 1) \mathrm{Cl}$ & 322 & 0.645 & 1290.00 & C.T. $M \rightarrow L$ \\
\hline $\mathrm{Zn}(\mathrm{L} 1) \mathrm{Br}$ & 307 & 1.068 & 2136.00 & C.T. M $\rightarrow$ L \\
\hline
\end{tabular}




\section{MTT assay}

MTT assay was used to determine the metal complexes cytotoxicity against human breast cancer cells MCF-7. This assay served as an index used to determine cytotoxicity of the metal complex to stimulate or inhibit cell viability and growth by detecting the reduction of tetrazolium salt to blue formazan by mitochondrial enzyme activity of succinate dehydrogenase in living cells. MCF-7 cells were treated with varying concentrations of the complexes for $48 \mathrm{~h}$, and the cells viabilities were measured by MTT assay. The metal complexes were found to inhibit the growth of MCF-7 cells in a dose-dependent manner (Table 4). The free ligand MTT assay showed no significant inhibition activities at a concentration even higher than the complex which confirmed that chelation of ligand with metal ions was significance for the activity of this novel compounds.

Table 4: EC50 values in $\mu \mathrm{g} / \mathrm{ml}$ of the tested compounds on WRL68 and MCF7 cell lines.

\begin{tabular}{llcc}
\hline Cpd. & & EC50 $\boldsymbol{\mu g} / \mathbf{m l}$ & \\
\hline & & WRL68 & MCF-7 \\
\hline $\mathbf{1}$ & $\mathrm{L} 1$ & n.d. & .d. \\
$\mathbf{2}$ & $\mathrm{Cu}(\mathrm{L} 1) \mathrm{Cl}$ & 41.15 & 37.58 \\
$\mathbf{3}$ & $\mathrm{Cu}(\mathrm{L} 1) \mathrm{Br}$ & 23.28 & 4.25 \\
$\mathbf{4}$ & $\mathrm{Zn}(\mathrm{L} 1) \mathrm{Br}$ & 52.26 & 33.09 \\
$\mathbf{5}$ & $\mathrm{Zn}(\mathrm{L} 1) \mathrm{Cl}$ & 32.69 & 10.94 \\
$\mathbf{6}$ & $\mathrm{Ni}(\mathrm{L} 1) \mathrm{Cl}$ & 13.05 & 8.15 \\
$\mathbf{7}$ & $\mathrm{Ni}(\mathrm{L} 1) \mathrm{Br}$ & 64.53 & 27.64 \\
$\mathbf{8}$ & $\mathrm{Mn}(\mathrm{L} 1) \mathrm{Cl}$ & 44.25 & 24.54 \\
$\mathbf{9}$ & $\mathrm{Mn}(\mathrm{L} 1) \mathrm{Br}$ & 4.65 & 5.93 \\
$\mathbf{1 0}$ & Cisplatin & - & 2.50 \\
\hline
\end{tabular}

\section{CONCLUSION}

In this paper we presented synthesis, characterization and cytotoxicity mediated by synthesized metal complexes on MCF-7 cells. In advanced, the study of mechanism of action (MOA) of the compound is suggested to further expand the knowledge on its target organism and application.

\section{ACKNOWLEDGMENTS}

The authors would like to thank the Department of Chemistry and the Institute of Biological Science, Faculty of Science, University of Malaya for the provision of laboratory facilities under the supervision of Prof. Dr. Hapipah Mohd Ali. The authors also wish to acknowledge the financial support provided by Umaru Musa Yar'adua University, P .M.B. 2218 Katsina Dutsin-ma Road +234, Katsina, Nigeria.

\section{REFERENCES}

Bagihalli, GB, Avaji, PG. Synthesis, spectral characterization, in vitro antibacterial, antifungal and cytotoxic activities of $\mathrm{Co}(\mathrm{II}), \mathrm{Ni}(\mathrm{II})$ and $\mathrm{Cu}(\mathrm{II})$ complexes with 1,2,4-triazole Schiff bases. Eur. J. Med. Chem. 2008; 43: 2639-2649.

Banerjee S, Wu B., Lassahn P-G, C. Janiak ., Ghosh A, Synthesis, structure and bonding of cadmium(II) thiocyanate systems featuring nitrogen based ligands of different denticity; Inorg. Chim. Acta 2005; 358: 535-544. Bases. Inorg. Chim. Acta 2010; 363: 4048-4058.

Bauer W, Polborn K, Beck W. Metal complexes of biologically important ligands, CXIV ferrocenyl-oxazolones as $\mathrm{N}$ and $\mathrm{C}$ donors in
Pd(II), Pt(II) and Ir(III) complexes and ferrocenoyl-dipeptides J. Organomet. Chem., 1999; 579: 269-279.

Bharti SK, Nath G, Tilak R, Singh SK. Synthesis, antibacterial and anti-fungal activities of some novel Schiff bases containing 2,4disubstituted thiazole ring. Eur. J. Med. Chem. 2010; 45: 651-660.

Bhowmik P, Chattopadhyyay S, Drew, MGB, Diaz C, Ghosh A. Synthesis, structure and magnetic properties of mono- and di-nuclear nickel(II) thiocyanate complexes with tridentate N3 donor Schiff bases Polyhedron 2010; 29: 2637-2642.

Ceyhan G, Çelik C. Antioxidant, electrochemical, thermal, antimicrobial and alkane oxidation properties of tridentate Schiff base ligands and their metal complexes. Spectrochim. Acta. 2011; 81: 184-198.

Chiumia GC, Craig DC, Phillips DJ, Rae AD, Kaifi FMZ.

Terminal S-coordinated thiocyanate in a nickel(II) complex.: X-ray structures of $\mathrm{Ni}($ poph $)\left(\mathrm{H}_{2} \mathrm{O}\right)(\mathrm{SCN})(\mathrm{NCS})$ and $\mathrm{Ni}($ poqh $)\left(\mathrm{H}_{2} \mathrm{O}\right)(\mathrm{NCS})_{2}$ (poph $=2$-pyridinecarboxaldehyde 1-oxide 2'-pyridinylhydrazone, poqh $=2$-pyridinecarboxaldehyde 1-oxide 2'-quinolynylhydrazone). Inorg. Chim. Acta. 1999; 285: 297-300.

Cotton FA, Wilkinson G. Advanced Inorganic Chemistry. Wiley-Interscience, New York 1998.

Creaven BS, Devereux M, Foltyn A, McClean S, Rosair G, Thangella VR, Walsh M. Quinolin-2(1H)-one-triazole derived Schiff bases and their $\mathrm{Cu}(\mathrm{II})$ and $\mathrm{Zn}$ (II) complexes: Possible new therapeutic agents. Polyhedron. 2010; 29: 813-822.

Creaven BS, Duff B, Egan DA, Kavanagh K, Rosair G, Thangella VR, Walsh M. Anticancer and antifungal activity of copper(II) complexes of quinolin-2(1H)-one-derived Schiff complexes. Polyhedron. 2009; 28: 3993-3998.

El-Sherif AA, Eldebss TMA, Synthesis, spectral characterization, solution equilibria, in vitro antibacterial and cytotoxic activities of $\mathrm{Cu}(\mathrm{II}), \mathrm{Ni}(\mathrm{II}), \mathrm{Mn}(\mathrm{II}), \mathrm{Co}$ (II) and $\mathrm{Zn}$ (II) complexes with Schiff base derived from 5-bromosalicylaldehyde and 2aminomethylthiophene. Spectrochim. Acta (A). 2011; 79: 1803-1814.

Garoufis A, Hadjikakou SK, Hadjiliadis N. Palladium coordination compounds as anti-viral, anti-fungal, anti-microbial and antitumor agents. Coord. Chem. Rev. 2009; 253: 1384-1397, 2009.

Hisham NAI, Gwaram NS, Khaledi H, Ali HM, Chlorido(2-\{1[(2-morpholinoethyl)imino]ethyl $\}$ phenolato- $\left.\kappa^{3}{ }^{3} N, N, O\right)$ copper(II). Acta Cryst. 2011; E67: m57.

Inamur RL, Tapas KM, Tian D, Debasis HL, Wing TW, Kenichi O, Nirmalendu RC. Syntheses, characterisation and solid state thermal studies of 1-(2-aminoethyl)piperidine (L), 1-(2-aminoethyl)pyrrolidine ( $\left.\mathrm{L}^{\prime}\right)$ and 4-(2-aminoethyl)morpholine ( $\left.\mathrm{L}^{\prime \prime}\right)$ complexes of nickel(II): X-ray single crystal structure analyses of trans- $\left[\mathrm{NiL}_{2}\left(\mathrm{CH}_{3} \mathrm{CN}\right)_{2}\right]\left(\mathrm{ClO}_{4}\right)_{2}$, trans$\left[\mathrm{NiL}_{2}(\mathrm{NCS})_{2}\right]$ and trans-[NiL" $\left.{ }_{2}(\mathrm{NCS})_{2}\right]$. Polyhedron, 2001; 20: $2073-$ 2082 .

Khan N-uH, Pandya N., Prathap KJ, Kureshy RI, Abdi SHR, Mishra S, Bajaj HC. Chiral discrimination asserted by enantiomers of $\mathrm{Ni}$ (II), $\mathrm{Cu}$ (II) and $\mathrm{Zn}$ (II) Schiff base complexes in DNA binding, antioxidant and antibacterial activities. Spectrochim. Acta. 2011; 81: 199208.

Mandal S, Karmakar TK, Ghosh A, Fleck M, Bandyopadhyay D. Synthesis, crystal structure and antibacterial activity of a group of mononuclear manganese(II) Schiff base complexes. Polyhedron. 2011; 30: 790-795.

Mladenova $\mathrm{R}$, Ignatova $\mathrm{M}$, Manolova $\mathrm{N}$, Petrova $\mathrm{T}$. Preparation, characterization and biological activity of Schiff basecompounds derived from 8-hydroxyquinoline-2-carboxaldehyde and Jeffamines ED. Eur. Polym. J. 2002; 38: 989-99.

Mohamed IM, Hapipah MA, Mahmood AA, Robinson TW. Synthesis, structural characterization, and anti-ulcerogenic activity of Schiff base ligands derived from tryptamine and 5-chloro, 5-nitro, 3,5ditertiarybutyl salicylaldehyde and their nickel(II), copper(II), and zinc(II) complexes. Polyhedron. 2009; 28: 3993-3998.

Moriuchi T, Nomoto A, Yoshida K, Hirao T. Characterization of ferrocene derivatives bearing podand dipeptide chains (-1-Ala-1-ProOR). J. Organomet. Chem. 1999; 589: 50-58

Moriuchi T, Nomoto A, Yoshida K, Ogawa A, and Hirao T. Chirality Organization of Ferrocenes Bearing Podand Dipeptide Chains: 
Synthesis and Structural Characterization J Am chem. Soc., 2000; 123: 6875.

Nair MS, Arish D. Synthesis, characterization and antimicrobial studies of CoII, NiII, CuII and ZnII complexes involving a bidentate Schiff base ligand J. Ind. Chem. Soc. 2010; 88: 265-270.

Nakamoto K. Infrared and Raman Spectra of Inorganic and Coordination Compounds. John Wiley \& Sons Inc, Atlanta, GA, U.S.A, 1978

Pandeya SN, Sriram D, Nath G, DeClercq E. Synthesis, antibacterial, antifungal and anti-HIV activities of Schiff and Mannich bases derived from isatin derivatives and N-[4-(4'-chlorophenyl)thiazol-2yl] thiosemicarbazide. Eur. J. Pharm. Sci.1999; 9: 25-31.

Petrovic N, Comi A, Ettinger MJ. Identification of an ApoSuperoxide Dismutase $(\mathrm{Cu}, \mathrm{Zn})$ Pool in Human Lymphoblasts. J. Biol. Chem., 1996; 271: 28331-28334.

Pignatello R, Panico A, Mazzone P, Pinizzotto MR, Garozzo A, Fumeri PM. Schiff bases of N-hydroxy-N'-aminoguanidines as antiviral, antibacterial and anticancer agents. Eur. J. Med. Chem. 1994; 29: 787-794.

Prakash A, Singh BK, Bhojak N, Adhikari D. Synthesis and characterization of bioactive zinc(II) and cadmium(II) complexes with new Schiff bases derived from 4-nitrobenzaldehyde and acetophenone with ethylenediamine. Spectrochim. Acta. 2010; 76: 356-362.

Raman N, Jeyamurugan R, Senthilkumar R, Rajkapoor B, Franzblau SG. In vivo and in vitro evaluation of highly specific thiolate carrier group copper(II) and zinc(II) complexes on Ehrlich ascites carcinoma tumor model. Eur. J. Med. Chem.2010; 45: 5438-5451.

Raman N, Selvan A, Sudharsan S. Metallation of ethylenediamine based Schiff base with biologically active $\mathrm{Cu}(\mathrm{II}), \mathrm{Ni}(\mathrm{II})$ and $\mathrm{Zn}(\mathrm{II})$ ions: Synthesis, spectroscopic characterization, electrochemical behaviour, DNA binding, photonuclease activity and in vitro antimicrobial efficacy. Spectrochim. Acta. 2011; 79: 873-883.

Selbin J, Marion C, Day MC. 1983. Theoretical Inorganic Chemistry Transition Elements, Reinhold, New York.

Shahabadi N., Kashanian S., Darabi F. DNA binding and DNA cleavage studies of a water soluble cobalt(II) complex containing dinitrogen Schiff base ligand: The effect of metal on the mode of binding. Eur. J. Med. Chem. 2010; 45: 4239-4245.

Shaker SA. Synthesis, Spectral and Magnetic Studies of Newly Mixed-Ligand Complexes of 4-Formyl-Acetanilide Thiosemicarbazone and 3,4-Dihydrocinnamic Acid with Some Metal Ions. E-Journal of Chemistry. 2010; 7(S1), S594-S600

Shakir M, Azam M, Ullah MF, Hadi SM. Synthesis, spectroscopic and electrochemical studies of N,N-bis[(E)-2thienylmethylidene]-1,8-naphthalenediamine and its $\mathrm{Cu}$ (II) complex: DNA cleavage and generation of superoxide anion. J. Photochem. Photobiol. 2011; 104: 449-456.
Shayma AS, Yang F, Abbas AS. Synthesis and Characterization of Mixed Ligand Complexes of 8-Hydroxyquinoline and ohydroxybenzylidene-1-phenyl-2,3-dimethyl-4-amino-3-pyrazolin-5-on with $\mathrm{Fe}(\mathrm{II}), \mathrm{Co}(\mathrm{II}), \mathrm{Ni}(\mathrm{II})$ and $\mathrm{Cu}(\mathrm{II})$ ions. Eur. J. Sci. Res. 2009; 33: $702-$ 709.

Shayma AS, Yang F, Sadia M, Eskender M. Synthesis and Characterization of Mixed Ligand Complexes of Caffeine, Adenine and Thiocyanate with Some Transition Metal Ions. Sains Malays. 2010; 39: 957-962.

Sridhar SK, Pandeya SN, Stables JP, Ramesh A. Anticonvulsant activity of hydrazones, Schiff and Mannich bases of isatin derivatives. Eur. J. Pharm. Sci. 2002; 16: 129-132.

Summerton JE, Morpholino, siRNA, and S-DNA compared: impact of structure and mechanism of action on off-target effects and sequence specificity. Curr. Top. Med. Chem. 2007;7(7):651-60.

Tajudeen, SS, Radha E. Synthesis, characterization and antimicrobial activity of transition metal complexes of schiff base derivatives from isonicotinic acid hydrazide. Asian J. Chem. 2009; 21: 313-316.

Wang MZ, Meng Z, Liu B, Cai G, Zhang C, Wang X. Novel tumor chemotherapeutic agents and tumor radio-imaging agents: Potential tumor pharmaceuticals of ternary copper(II) complexes Inorg.Chem. Comm.2005: 8: 368371.

Xue LW, Zhao GQ, Han YJ, Feng YX. Synthesis, Structures, and Antimicrobial Activity of Schiff Base Zinc Complexes with Thiocyanate and Iodide. Synth. React. Inorg. Met. -Org.Nan.Met.Chem. 2011; 41: 141-146.

Yusnita J, Puvaneswary S, Mohd AH, Robinson WT, Kwi-Lin T. Synthesis, structural characterization and antibacterial activity of 2,6diacetylpyridine bis(benzenesulfonohydrazide) Schiff bases and their copper(II) complexes. Polyhedron. 2009; 28: 3050-3054.

Yusnita J, Puvaneswary S, Mohd AH, Robinson WT, Kwai-Lin T. Synthesis, structural characterization and antibacterial activity of 2,6diacetylpyridine bis(benzenesulfonohydrazide) Schiff bases and their copper(II) complexes. Polyhedron. 2009; 28: 3050-3054.

Zhang J-A, Pan M, Zhang J-Y, Kang B-S, Su C-Y. Syntheses, structures and bioactivities of cadmium (II) complexes with a tridentate heterocyclic N- and S-ligand. Inorg. Chim. Acta. 2009; 362: 3519-3525.

\section{How to cite this article:}

Nura Suleiman Gwaram, Pouya Hassandarvish. Synthesis, characterization and anticancer studies of some morpholine derived Schiff bases and their metal complexes. J App Pharm Sci, 2014; 4 (10): 075-080. 